\title{
Investigating the Total Losses of Water in the Entire Drinking Water Supply System: The Case of Debre Tabor Town, Ethiopia
}

\author{
Abel Amsalu Ayalew
}

\begin{abstract}
Safe and adequate drinking water is the most vital human rights and necessities, it is critical for life and economic activities, but drinking water shortage is the primary cause of livelihoods and economic crisis because of drastic water losses in the water supply system. This study aimed to investigate the current crucial issue of drinking water losses in the entire water supply system using water meter at the source of supply, at the transfer pump station and at the water demand areas for Debre Tabor Town, Ethiopia. Therefore, the total volume of water loss in the transmission pipelines was covered $33.32 \%$ and distribution network has $27.96 \%$ water lose. Therefore, an average losses of water in the town is not recommended. And, increased by one cubic meter in one unit increase of water production at the source due to poor operations and maintenances in the pipelines. However, it could be reduced by one cubic meter through one unit increasing of water at the transfer pumps and at the distribution reservoirs by the means of proper operations and maintenance of transmission and /or the distribution pipelines. Therefore, due to this drastic water losses, the maximum numbers of households were supplied pipe water once per 15 days and cluster two supplied in 20 days.
\end{abstract}

Keywords: loss, billed water, unbilled water, authorized water and NRW.

DOI: $10.7176 / \mathrm{CER} / 13-1-03$

Publication date: January $31^{\text {st }} 2021$

\section{INTRODUCTION}

Water is a gift of nature to human, paramount importance, and vital. It is a fundamental human right (Chaminuka \& Nyatsanza, 2013), and it is the most important natural resources. Which plays an important role in making life is comfortable and luxurious. However, water shortage has a major impact on human activity, and developments. Therefore, managing of water losses in the entire water supply system is one of the best solutions for drinking water shortage. It is foremost obligation of water utility for providing safe and continuous water supply. However, nowadays water loss is a major challenging factor for many water utilities especially in developing countries (Asmelash, 2014) as well as in Ethiopia, particularly in Debre Tabor town. Water lose is the defect of water in the water supply system before reaching the customer because of deteriorated pipelines, overflow, and illegal water connections. It is subjected to decreasing hydraulic capacity and water quality deteriorations (Jang, 2018). UFW is the difference in total water production and authorized water. Whereas, authorized water is the summation of billed and unbilled authorized water. The water used for fire extinguishing, pipe pressure test, reservoir and street washing is common unmetered and unbilled authorized water. However, public taps water is unmetered but revenue water. The illegal connection, metering inaccuracy and leakages are some mutual forms of unauthorized also unbilled and UFW. However, the household's water demand for domestic and non-domestic demand is authorized likewise accounted and billed water. In general, the drinking water demand can be articulated as revenue water (metered billed) and NRW water demand. NRW is the water from unbilled authorized and the total losses of water in the system (Jang, 2018), it included leakages, metering inaccuracy, illegal connection and unmetered unbilled water. The water from reported and unreported bursts, reservoir leakage, overflow and leakage from valves and pumps are real (physical) water losses, whereas metering inaccuracy and illegal connections are apparent (minor) losses (Hoko \& Alida, 2017). Therefore, not all water losses are leakage but it is UFW and NRW. Also, all unbilled authorized water is not leakage and UFW loss, whereas it is NRW. For a general speaking, all leakages and UFW are nonrevenue water, however all NRW is not UFW.

The largest component of UFW is real losses and it driven by pressure and old age of pipes, also it is a significant portion of NRW (Hoko \& Alida, 2017). Similarly, UFW is caused by a lack of active leakage prevention, poor assistance, operations and maintenance (Jang, 2018), also poor control of illegal connections, lack of awareness and attitudes of the residents. The low NRW has designated proper management of water supply system (Jang, 2018). The developing countries have poor operation and maintenance and not given more attention as new water work construction and system extensions (Hoko \& Alida, 2017). The real losses of water could be reduced by pressure management and pipe replacement (Hoko \& Alida, 2017). However, an apparent loss could be reduced by metering calibration, besides wireless sensor networks are substantial for collecting and communicating the flow measurement for leakage detection (Balogun et al., 2017). The collective NRW data is critical for prioritizing the distribution network (Jang, 2018).

Due to this, as per (Amhara Water Resources Bureau, 2012) UFW for large and medium towns is $40 \%$ and for small and rural areas 26\%. UFW should be $40 \%, 25 \%$ to $30 \%$ for Addis Ababa and other towns generally, 50\% loss is not precedent and $15 \%$ is good and it is uneconomical try to reduce (Water Supply \& Sanitation, 2019). 
According to WHO, out of the total supplied water industrialized countries have $8 \%-24 \%$, middle income (newly industrialized countries) $15 \%-24 \%$ and developing countries has $25 \%-45 \%$ UFW losses is recommended.

\section{Summary of Theoretical Frameworks}

According to the literature evidence base, the limited access to water demand is an intermittent supply and it caused by technical and operation problems of the project scheme and poor efficiency of installed capacities. However, water is a priority of social and economic development but it affected by water shortage due to drastic water losses and drinking water crisis is too much dangerous. Nevertheless, it can be alleviating by proper water lose management, water sources management and reusing of wastewater for both quantity and quality aspects. The most cause of drinking water shortage is rapid population growth, design limitations, installed capacity problems, leakages (losses) and economic water scarcity. In addition, pressure and urbanizations are the cause of drinking water shortage.

\section{MATERIALS AND METHODS \\ Descriptions of the Study Area}

The study was carried out at Debre Tabor town in north of Ethiopia which is located in the South Gondar administrative zone of Amhara national regional state. It is situated at Northwest Ethiopian highlands about $55 \mathrm{~km}$ northeast of Lake Tana (Alubel, 2018), 110km from Bahir Dar, and 666km from Addis Ababa. Geographically the town is located at $38^{\circ} 00^{\prime} 17.016^{\prime}$ 'E and $11^{0} 51^{\prime} 29.309^{\prime}$ 'N with an average altitude of $2717 \mathrm{~m}$. The town served as the seat of the Yeju Dynasty during1769 to 1855, the capital city of Ethiopia during Emperor Tewodros II from 1855 to 1868 and second capital during Emperor Yohannes IV (1872 to 1889) also continued as a seat of Ras Gugsa Wole governor of the area in early $20^{\text {th }}$ century (Alubel, 2018). The name "Debre Tabor" is derived from Mount Tabor of the Bible in Jerusalem which has a similar landscape to Iyesus Mountain in Debre Tabor and on top of the mountain is Iyesus Church (Alubel, 2018). It has 66\% mountainous, $20 \%$ plain, and 14\% rocky (Alubel, 2018). The town had a moderate climate with $13^{\circ} \mathrm{C}$ to $18^{\circ} \mathrm{C}$ average annual temperature and having a mean annual rainfall of $1589.7 \mathrm{~mm}$ (Debre Tabor Water Supply Design Report, 2019). Currently, the town is a center of SouthGondar administrative zone with Farta and Debre Tabor town administrations. It has $10 \mathrm{KGs}, 6$ general primary schools, 5 secondary and preparatory schools, 7 colleges and one university (DTU) in the education sector, and three health centers and one referral hospital in the health sector. The town has 8 Orthodox and one kale-hiowt Churches, one mosque and it has 16832 households, 100992 total numbers of people out of these 45739 males, and 55253 females with an average family size of 6 people. The town has six Kebeles and surrounded by Farta wereda correspondingly in East Hiruy-Abaregay, in West Tsegur-Adiko, North Weibla-Selamiko, and the south Iyesus. Currently the town has 10 boreholes from four sites, named as Tegure, Ajibar, Selamko, and Kanate which are used for town drinking water supply sources.

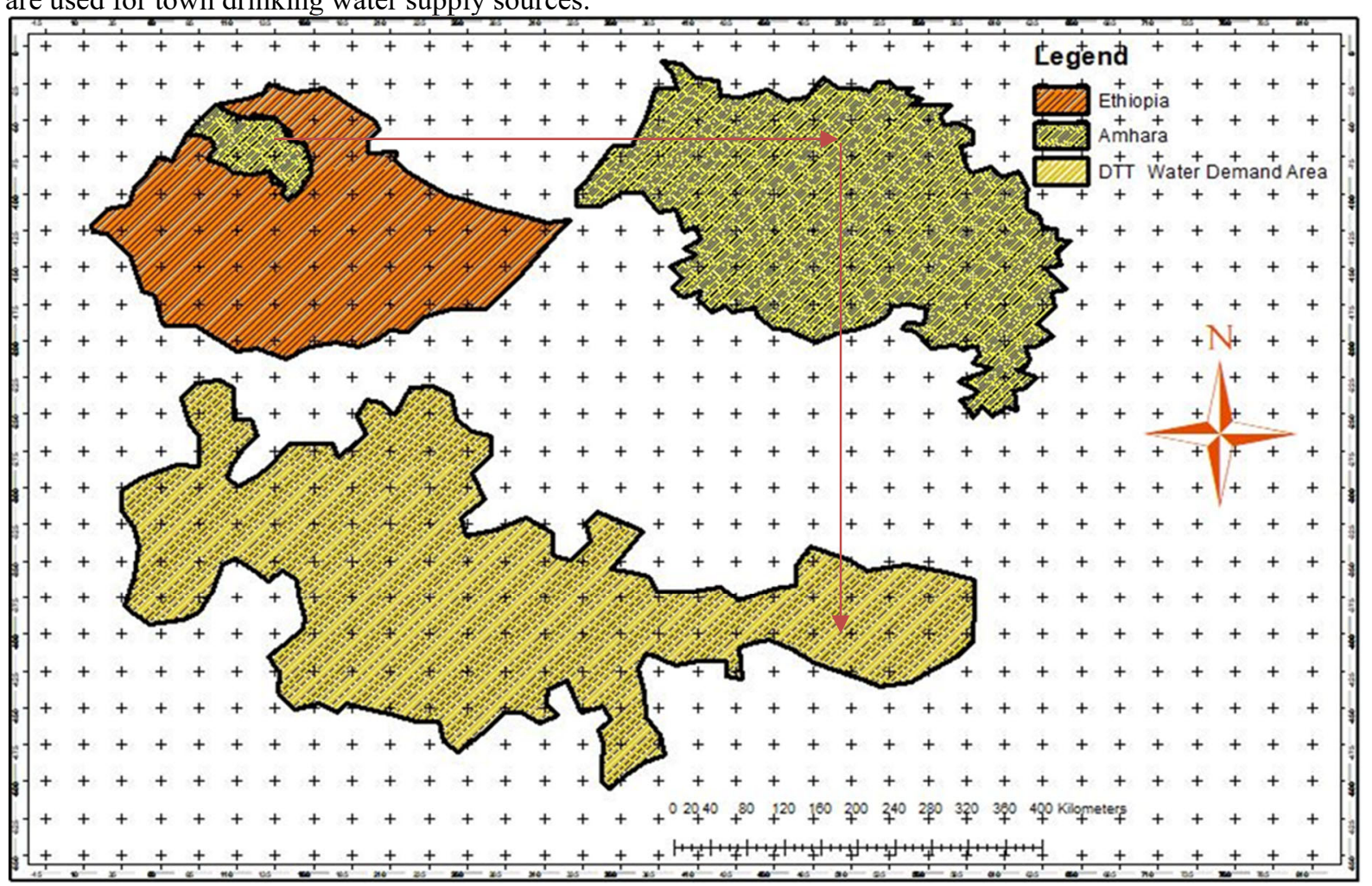

Figure 1.2.1 Background of the study area for Debre Tabor town 


\section{The Research Process}

The study conducted the total and actual water supply for analysis water losses (total UFW). It was investigate the capacity of all boreholes and its total supply of water was a common task for evaluating the total productions of water. The actual supply of water was examined from the total billed and authorized unbilled water in the town and it was evaluated before UFW was conducted. The billed water data was investigated from the water utility for one year from March 2019 to February 2020. Whereas, unbilled authorized volume of water was collected from the governmental and non-governmental organizations. Therefore, the total UFW was evaluated from the total water production and the total authorized water demand through water meter. The total NRW is the association of total UFW and authorized but unbilled water demand in the town.

\section{Data Collection Instrument and Data Nature}

UFW are used quantitative data nature which was examined numerically and it used for mathematical calculations. These data was investigated interims of primary and secondary data sources. The volume of supplied water was measured by water meter at the source, at the transfer pump stations, and at the demand area. However, secondary data (billed water data) were collected from the town water utility.

\section{Analysis of Unaccounted for Water (UFW) Losses}

The production of water in the entire water supply system is the sum of consumption volume of water per time and the total volume of water losses (Hoko \& Alida, 2017). However, water demand analysis is influenced by NRW since leakage management is difficult (Jang, 2018), because investigation of illegal connections are sophisticated. The analysis of UFW is conducted over the difference of supplied water and billed consumptions (Hoko \& Alida, 2017), I disagree because it is NRW. Therefore, UFW analysis conducted by the difference of supplied water and authorized water consumptions.

Statistically the volume of water produced from the source of supply; water at transfer pump and losses of water in the transmission pipeline (TPLs). Also, the supplied volume of water after the pump house (PH); consumed water in the town and water losses in the distribution network. Similarly, the total production of water; actual supply; total water losses; water loss in the distribution network and loss in TPLs were analyzed by multiple regression and it is associated with bivariate correlations.

Mathematically for $\mathrm{Q}_{\mathrm{p}}$ is the total production of water, UFW at authorized water demand (Qa) was formulating as Equation 19. Nevertheless, the total consumption of water is billed and authorized unbilled water (Qau) and it was formulating as Equation 20. UFW is the percentage of total supplied water and it is a total volume of water losses (Hoko \& Alida, 2017). Whereas, according to (Hoko \& Alida, 2017) the total volume of water losses per time is nonrevenue water, I disagree, all losses of water are NRW but all NRW are not losses.

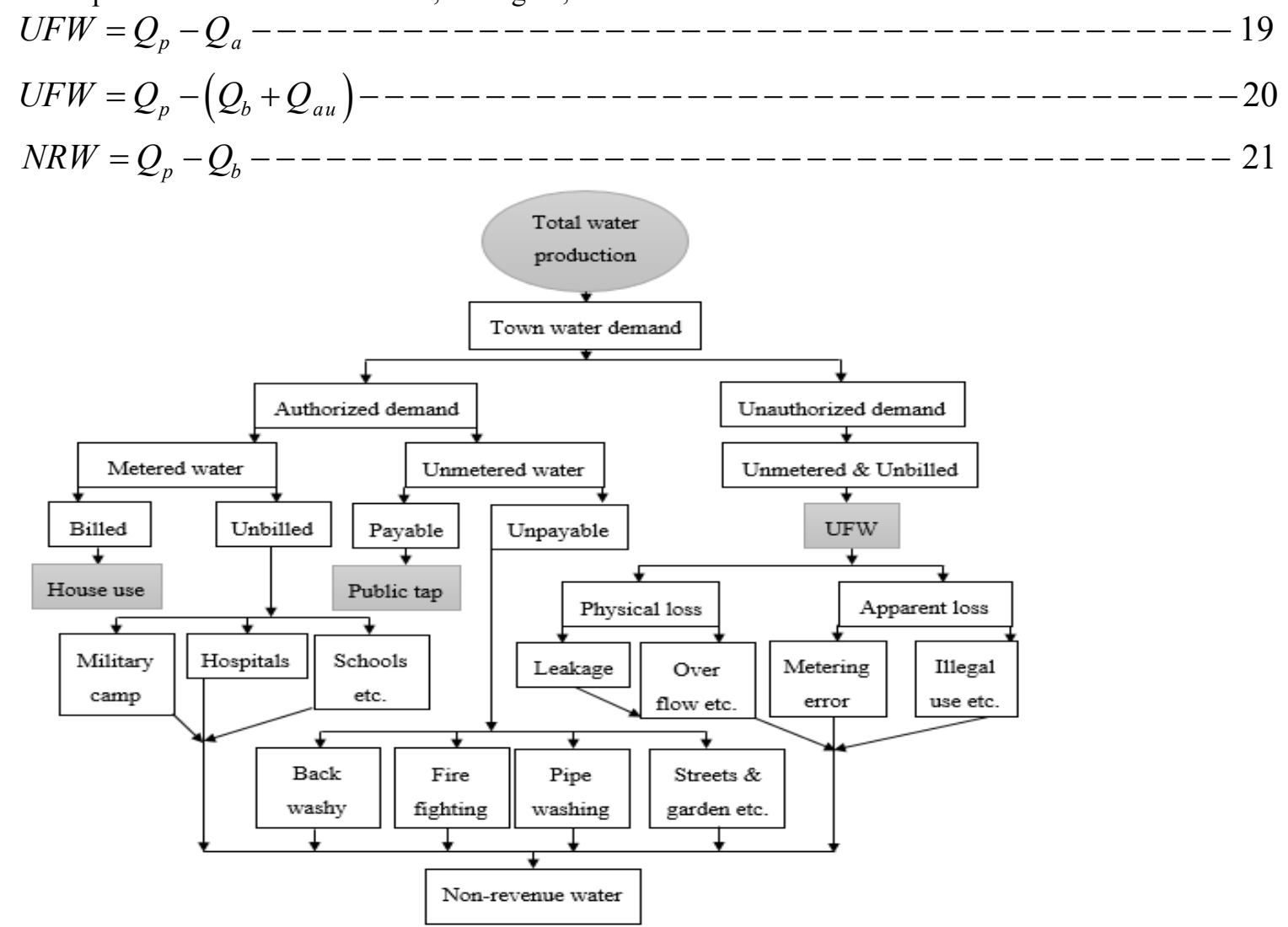

Figure 3.5.3 Investigation of UFW and NRW in the water supply system 


\section{RESULTS AND DISCUSSION}

\section{The Production of Water}

The result of monthly production of water is signified in Figures 4.3.1 and 4.3.2 it shows the production of water from 10 deep boreholes. From those Kanate water supply project was constructed in 2014, however still there is not legally certified between the contractor and the client until 2021. The result of monthly maximum and minimum production volume of water per day is shown in Table 4.3.1. It shows most water supply boreholes volume of production is limited during the dry season (May).

The Kanate water supply project deep boreholes were produced $1211.96 \mathrm{~m}^{3} / \mathrm{d}$ volume of water from four boreholes and Selamko water supply project boreholes were produced $886.96 \mathrm{~m}^{3} / \mathrm{d}$ from four boreholes. In addition, Ajibar and Tegure drinking water supply boreholes were produced $74.83 \mathrm{~m}^{3} / \mathrm{d}$ and $134.65 \mathrm{~m}^{3} / \mathrm{d}$ volume of water respectively. All water supply deep boreholes had local access roads which are difficult in rainy seasons. Due to this, the two high rainy months had an average production volume of water as shown in Figure 4.3.2 B, because of poor operation and maintenances especially for boreholes 9, 5 and 6. From the result of the average production of water from 10 boreholes, $25.4 \%$ of the water was supplied from Kanate borehole number two and it is the maximum production of water. Out of the total town water supply, 52.91\% of water was produced from the Kanate water supply project, out of this borehole number one, three and four were supplied $4.37 \%, 11.13 \%$ and $12.02 \%$. In addition, borehole five, six, seven and nine were supplied $10.42 \%, 4.98 \%, 16.86 \%$ and $5.68 \%$. The borehole eight and ten were covered $3.27 \%$ and $5.88 \%$ from the total town water supply respectively.

Table 4.3.1 Debre Tabor town water supply scheme monthly max and min production $\left(\mathrm{m}^{3} / \mathbf{d}\right)$

\begin{tabular}{l|cccccccccc}
\hline Source & Well 1 & Well2 & Well3 & Well4 & Well5 & Well6 & Well7 & Well8 & Well9 & Well10 \\
\hline Max & 131.4 & 718.8 & 333.7 & 358.1 & 271 & 183.8 & 396.9 & 90.5 & 197.6 & 167 \\
Min & 64.6 & 374.5 & 215.7 & 128.2 & 189.9 & 72.3 & 377.2 & 65.1 & 85 & 100.3 \\
\hline
\end{tabular}

Table 4.3.2 Debre Tabor town water supply scheme average production of water in $\mathrm{m}^{3} / \mathrm{d}$

\begin{tabular}{l|ccccccccccc} 
Source & Well 1 & Well2 & Well3 & Well4 & Well5 & Well6 & Well7 & Well8 & Well9 & Well10 & Total \\
\hline Aveg Supply & 100.1 & 581.8 & 254.9 & 275.2 & 238.7 & 114 & 386.1 & 74.8 & 130.1 & 134.6 & 2290.41 \\
\hline
\end{tabular}
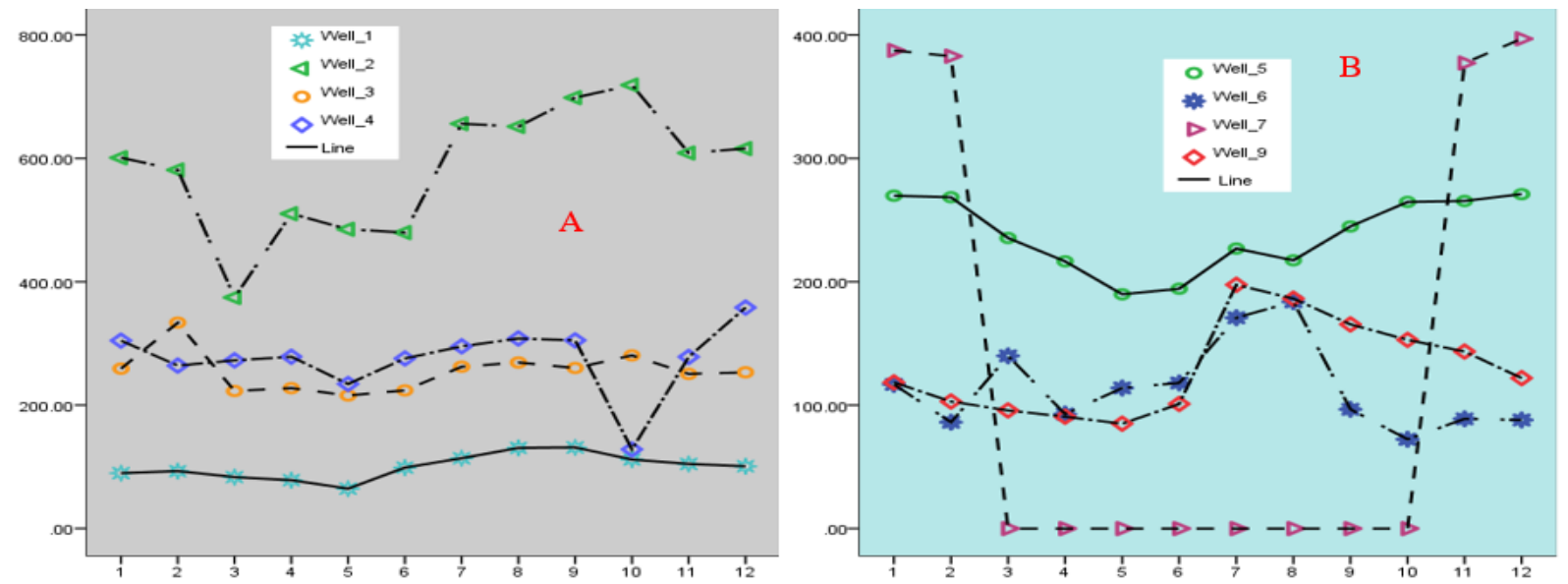

Figure 4.3.1 Kanate (A), Selamko (B) water production from Jan to Dec (1 to 12$) \mathrm{in}^{3} / \mathrm{d}$ 

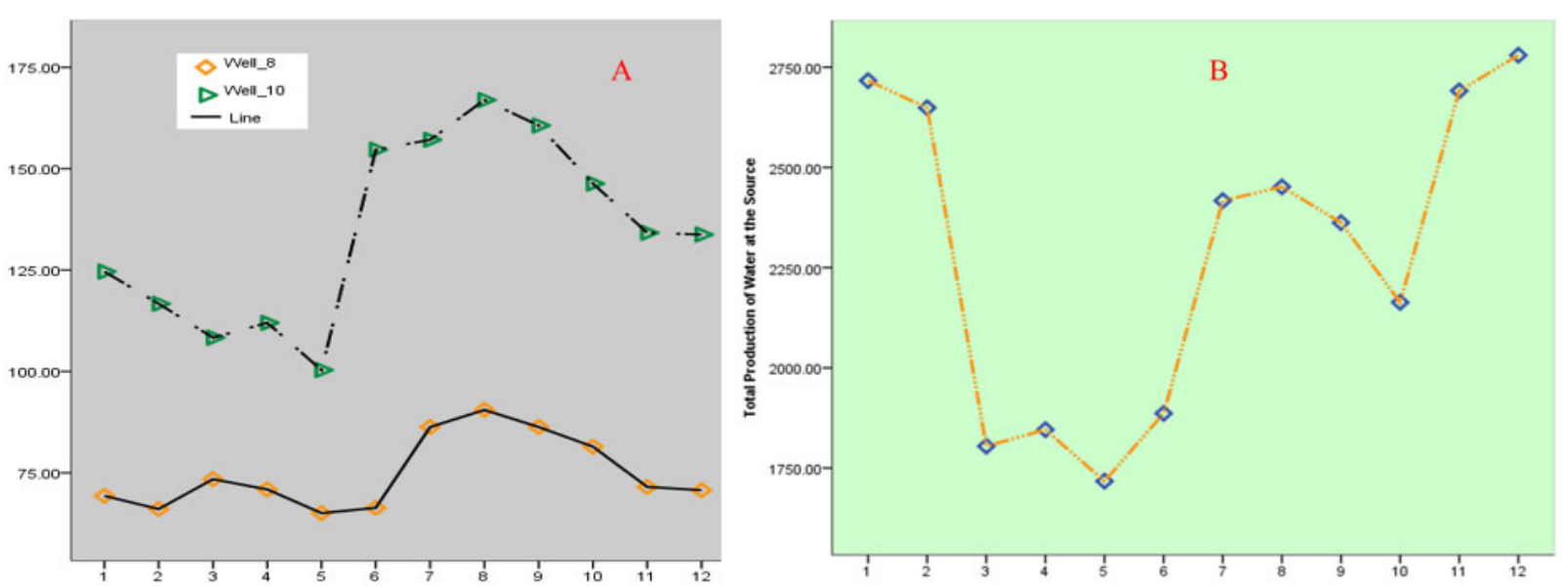

Figure 4.3.2 Tegure and Ajibar (A), total production (B) from Jan to Dec (1 to 12) in $\mathrm{m}^{3 / \mathrm{d}}$

Unaccounted for Water (UFW)

Water Losses in the Transmission Pipe Lines (TPL)

The Debre Tabor town water supply scheme TPL and collector pipelines are shown in Figure 4.4.1. The result shows, it has 9 collector pipelines from each wells to the transfer pump stations $(\mathrm{PH})$ and it has five major water supply TPLs after each transfer pump station.

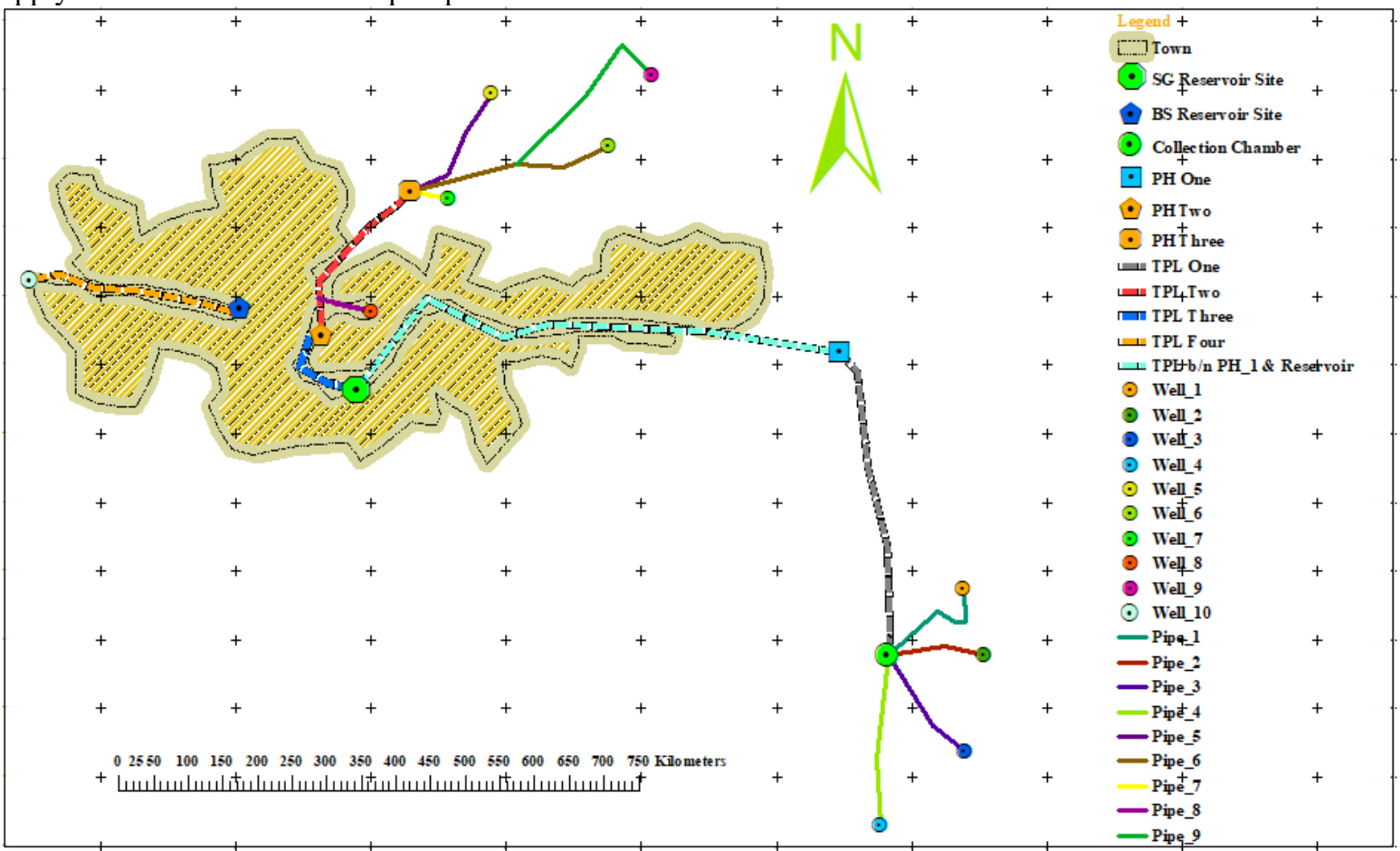

Figure 4.4.1 Debre Tabor town drinking water supply scheme transmission pipeline layouts

Water Losses before PH-1 (TPL 1)

The pipelines from each borehole to the gravity collection chamber and the PH1 are represented as transmission pipeline one (TPL1). The result of water losses trend before PH1 is represented as Figure 4.4.2. An average losses of water over a year out of the total production of water was $253.01 \mathrm{~m}^{3} / \mathrm{d}$ it covered $11.05 \%$. The lowest water loss occurred in July with $5.92 \%\left(71.7 \mathrm{~m}^{3} / \mathrm{d}\right)$ from the total Kanate water production and the highest water losses occurred in September with $40.64 \%\left(492.5 \mathrm{~m}^{3} / \mathrm{d}\right)$. The total losses of water in TPL1 covered $11.05 \%$ which are in the range of the total allowable loss standard for industrialized countries set by WHO ( $8 \%$ to $24 \%)$. Therefore, it could be concluded that the average losses of water through TPL1 are not recommended and the pipeline is deteriorated and /or it has a low pump capacity because of high elevation difference. UFW losses for TPL1 are presented in Table 4.4.1.

Table 4.4.1 Water losses in the transmission pipeline one in cubic meter per day

\begin{tabular}{l|cccccccccccc}
\hline Month & Jan & Feb & Mar & Apr & May & Jun & Jul & Aug & Sep & Oct & Nov & Dec \\
\hline Losses & 311.29 & 382.25 & 76.25 & 282.56 & 243.44 & 136.41 & 71.7 & 340.17 & 492.5 & 260.51 & 237.33 & 201.67 \\
\hline
\end{tabular}



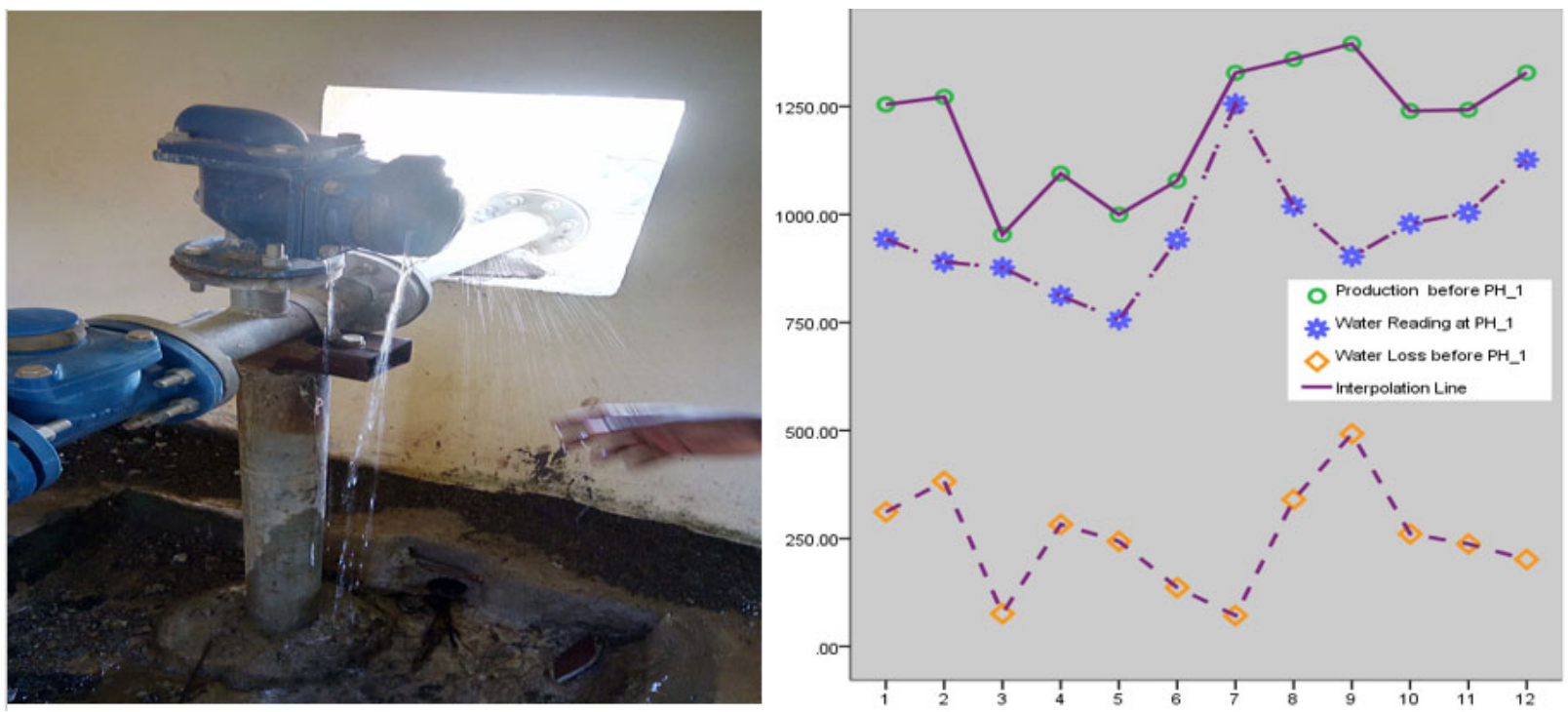

Figure 4.4.2 Water losses in transmission pipeline one from Jan to Dec (1 to 12) in $\mathrm{m}^{3} / \mathrm{d}$

The loss of water in the TPL1 has a unit coefficient of determination and negative $\beta o$. Whereas, it has one and a negative one of $\beta 1$ and $\beta 2$ over the analysis of water production before PH1 and the volume of water at PH1 respectively. It indicates that water losses in TPL1 are increased by one cubic meter in every one unit increasing volume of water at the source. Similarly, the loss of water in TPL1 would reduce by one cubic meter in every one unit increasing volume of water at PH1.

Table 4.4.2 Bivariate association of water losses in the transmission pipeline one

\begin{tabular}{l|cccc}
\hline \multicolumn{1}{c|}{ Correlations } & Loss before PH_1 & Month & Production before PH_1 & Water at PH_1 \\
\hline Loss before PH_1 & 1 & 0.006 & 0.505 & -0.367 \\
Month & 0.006 & 1 & 0.466 & 0.497 \\
Production before PH_1 & 0.505 & 0.466 & 1 & 0.617 \\
Water at PH_1 & -0.367 & 0.497 & 0.617 & 1 \\
\hline
\end{tabular}

\section{Water Losses before PH-3}

The pipelines from each wells to the transfer pump three are represented as collector pipelines before PH3. The percentage losses of water in the collector pipelines before PH3 was $18.3 \%$ out of the total supplied water $\left(419.4 \mathrm{~m}^{3} / \mathrm{d}\right)$ before PH3. The result of water loss before PH3 is represented as Figure 4.4.3 and in Table 4.4.3. The loss of water in collector pipelines before PH3 was higher than the total volume of water at PH3 in June, July and November.

\section{Table 4.4.3 Water losses through collector pipelines before $\mathrm{PH} 3$ in $\mathrm{m}^{3} / \mathrm{d}$}

\begin{tabular}{l|cccccccccccc}
\hline Month & Jan & Feb & Mar & Apr & May & Jun & Jul & Aug & Sep & Oct & Nov & Dec \\
\hline Losses & 493 & 441.6 & 349.8 & 277.7 & 279.96 & 320.5 & 551.9 & 417.2 & 308 & 326.3 & 676.7 & 589.9 \\
\hline
\end{tabular}
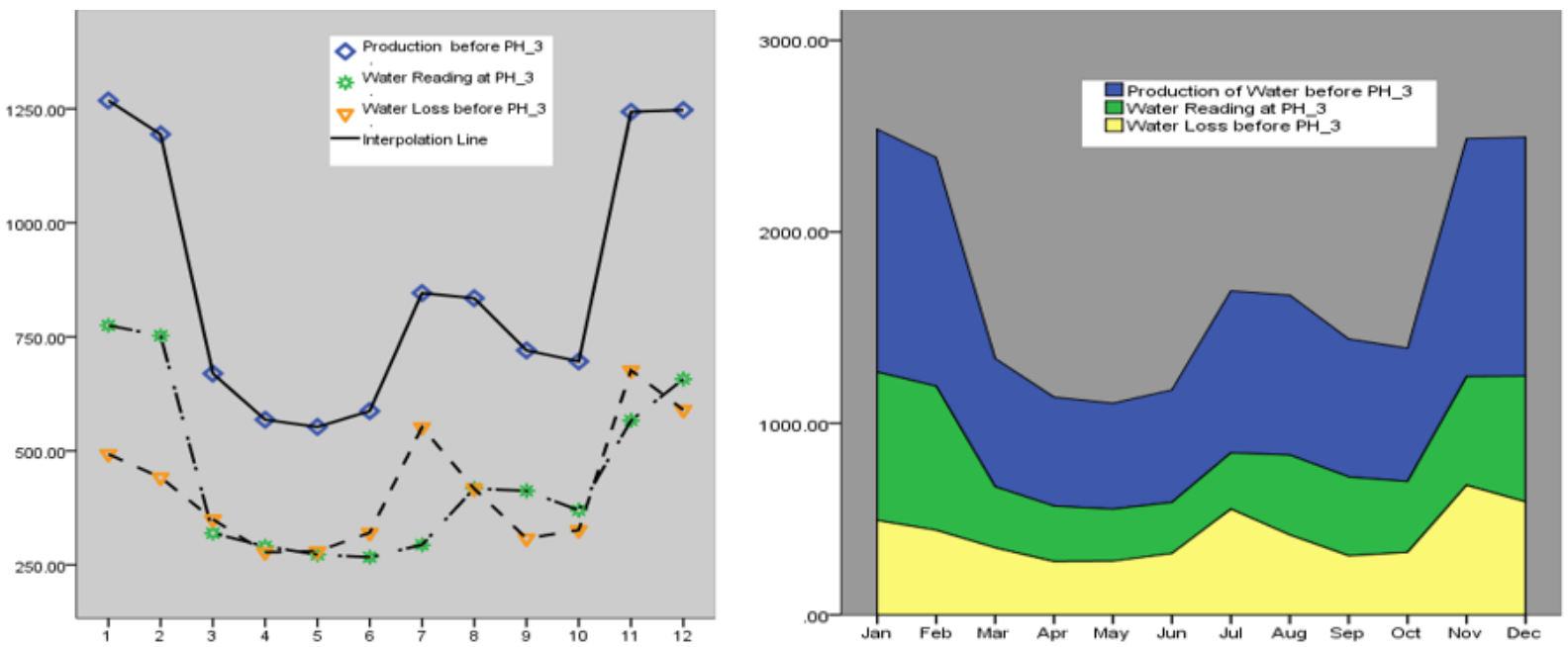

Figure 4.4.3 Water loss in collector pipelines before $\mathrm{PH} 3$ from Jan to Dec (1 to 12) in $\mathrm{m}^{3} / d$

The losses of water in the pipeline were increased by $1 \mathrm{~m}^{3} / \mathrm{d}$ in every $1 \mathrm{~m}^{3} / \mathrm{d}$ increasing volume of water production. 
Whereas, the losses of water in collector pipelines before PH 3 would reduce by $1 \mathrm{~m}^{3} / \mathrm{d}$ in every $1 \mathrm{~m}^{3} / \mathrm{d}$ water increasing at PH3. The losses of water in the collector pipelines and months in a year have high associations since the losses of water were increased during the rainy season because of poor operation and maintenance due to access road problems.

Table 4.4.4 Bivariate associations of water losses in collector pipelines before $\mathrm{PH} 3$

\begin{tabular}{l|cccc}
\hline Correlations & Loss before PH3 & Month & Production before PH3 & Reading at PH3 \\
\hline Loss before PH3 & 1 & 0.362 & 0.846 & 0.584 \\
Month & 0.362 & 1 & 0.099 & -0.103 \\
Production before PH3 & 0.846 & 0.099 & 1 & 0.927 \\
Reading at PH3 & 0.584 & -0.103 & 0.927 & 1 \\
\hline
\end{tabular}

Water Losses between PH-2 and PH-3 (TPL 2)

The transmission pipeline two (TPL 2) laid between PH3 and PH2. It used to transfer water from PH3 and Ajibar deep borehole (well 8) to the PH 2. Therefore, the volume of water boosting through the TPL2 is the daily volume of water meter reading at $\mathrm{PH} 3$ and the daily production volume of water from borehole 8 . The average losses of water over a year through TPL2 from the total production of water in the system were covered $3.96 \%\left(90.72 \mathrm{~m}^{3} / \mathrm{d}\right)$.

Table 4.4.5 Transmission pipeline two daily cubic meter water losses

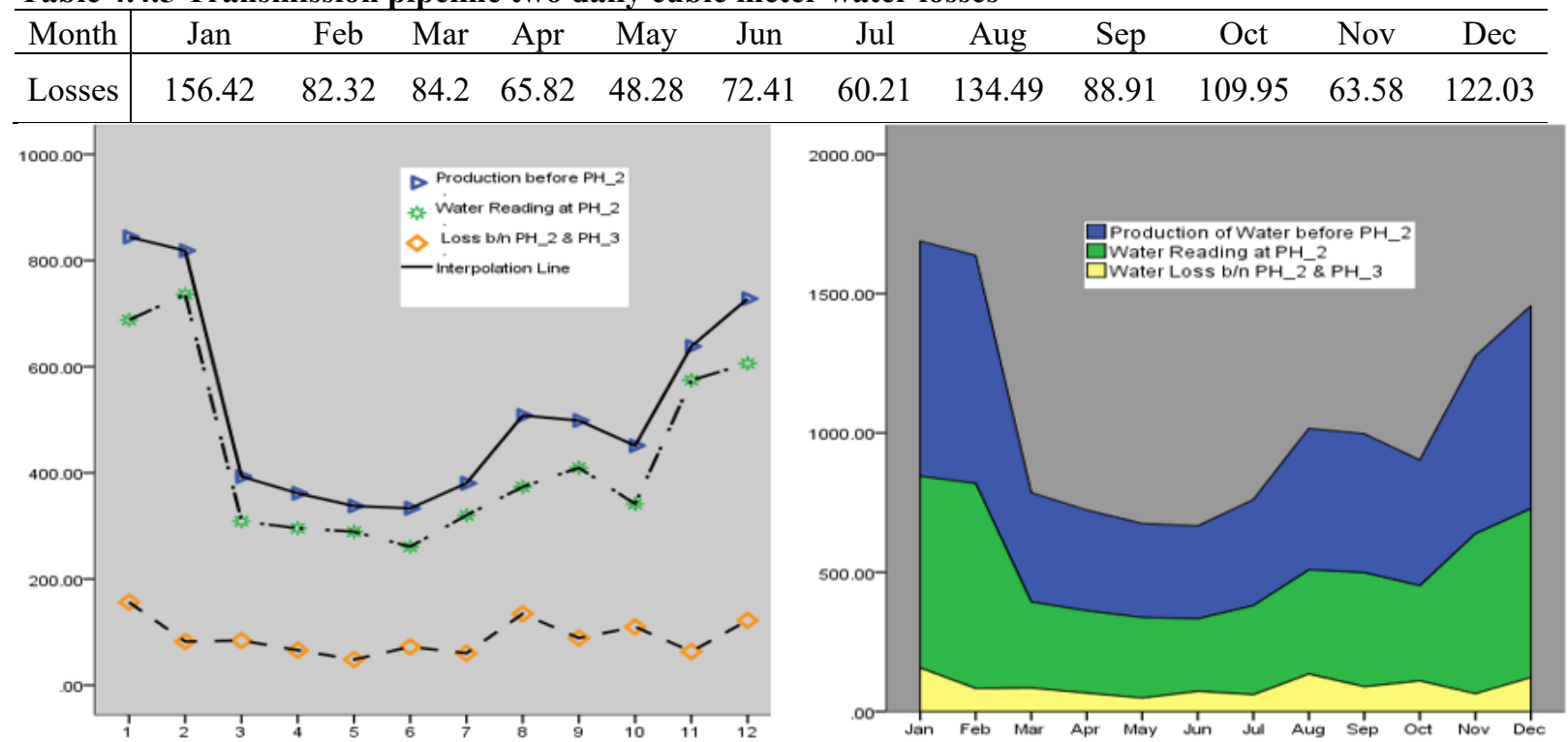

Figure 4.4.4 Water losses in transmission pipeline two from Jan to Dec (1 to 12) in $\mathrm{m} 3 / \mathrm{d}$

The losses of water in TPL2 were increased by $1 \mathrm{~m}^{3} / \mathrm{d}$ in every $1 \mathrm{~m}^{3} / \mathrm{d}$ increasing volume of water from PH3 with a unit coefficient of determination. However, the losses of water would be reduced by $1 \mathrm{~m}^{3} / \mathrm{d}$ through one unit increasing of water at $\mathrm{PH} 2$.

Table 4.4.6 Bivariate association of losses of water in transmission pipeline two

\begin{tabular}{l|cccc}
\hline \multicolumn{1}{c|}{ Correlations } & Loss b/n PH2 \& PH3 & Production before PH2 & Water at PH2 & Month \\
\hline Loss b/n PH2 \& PH3 & 1 & 0.592 & 0.458 & -0.002 \\
Production before PH2 & 0.592 & 1 & 0.988 & -0.084 \\
Water at PH2 & 0.458 & 0.988 & 1 & -0.093 \\
Month from & -0.002 & -0.084 & -0.093 & 1 \\
\hline
\end{tabular}

\section{Water Losses in the Distribution Network (DN)}

The losses of water in the distribution network (DN) were investigated through the actual supply of water and water from PH1, PH2 and water from well 10. The result of water losses in the DN is shown as figure 4.4.5. This shows, the losses of water in the DN were higher than the actual supply of water, particularly over July and August. An average daily losses of water in the entire DN are shown in table 4.4 .7 , which is covered $27.96 \%\left(640.4 \mathrm{~m}^{3} / \mathrm{d}\right)$ from the total supplied water. The particular percentage of water losses in the DN is higher than the total acceptable water losses standard set by (Amhara Water Resources Bureau, 2012) (26\%).

Table 4.4.7 Losses of water in the distribution network in cubic meter per day

\begin{tabular}{l|cccccccccccc}
\hline Month & Jan & Feb & Mar & Apr & May & Jun & Jul & Aug & Sep & Oct & Nov & Dec \\
\hline Losses in DN & 761.7 & 748.5 & 382.6 & 255.1 & 308 & 603.9 & 891.9 & 856.2 & 731.5 & 701.5 & 794.7 & 649.1 \\
\hline
\end{tabular}



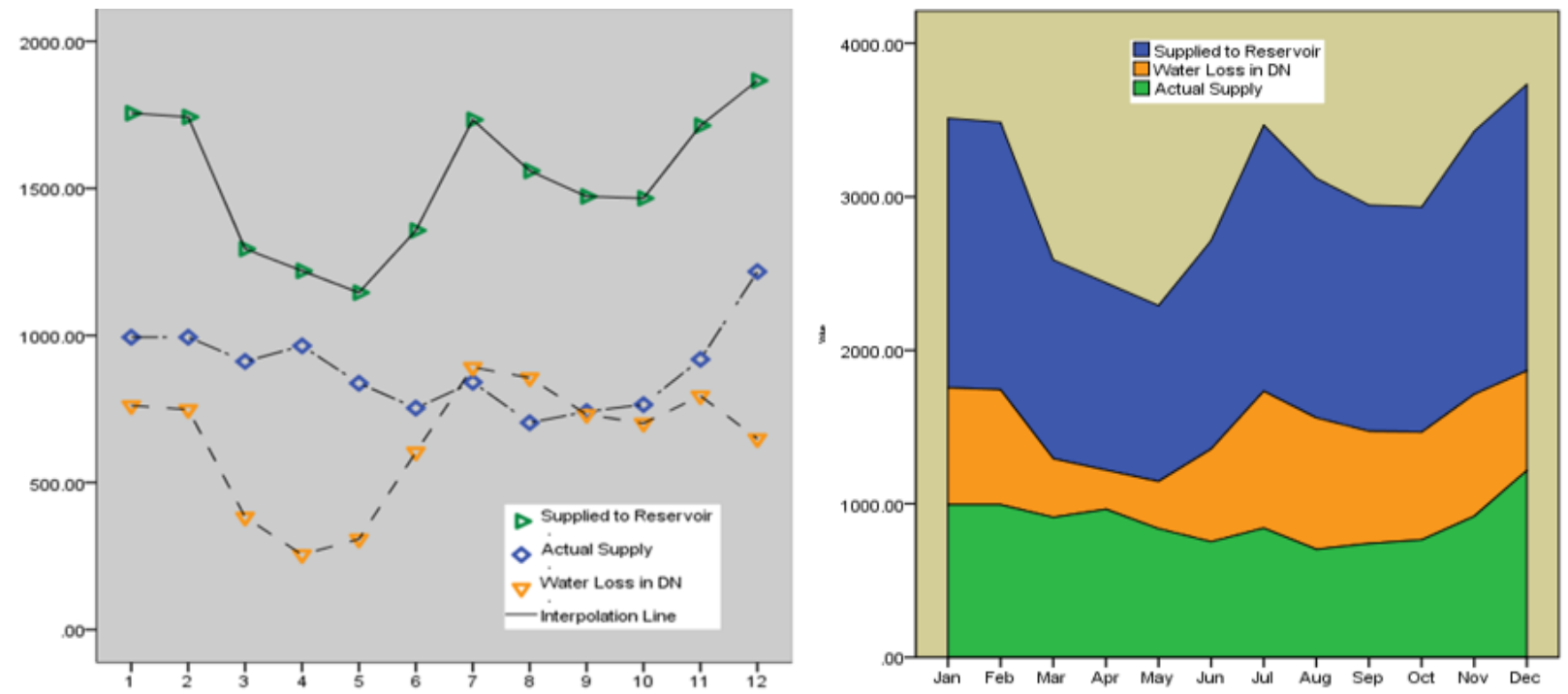

Figure 4.4.5 Water losses in the distribution network from Jan to Dec (1 to 12) in $\mathrm{m}^{3} / \mathrm{d}$

The daily losses of water in the DN were increased by $1 \mathrm{~m}^{3} / \mathrm{d}$ over $1 \mathrm{~m}^{3} / \mathrm{d}$ increasing of water from PHs, whereas it would reduce by $1 \mathrm{~m}^{3} / \mathrm{d}$ when consumed water increased by $1 \mathrm{~m}^{3} / \mathrm{d}$. Therefore, the losses of water in the DN have direct and inverse relationships with the actual supply of water in the system.

Table 4.4.8 Bivariate association of water loss in the distribution system

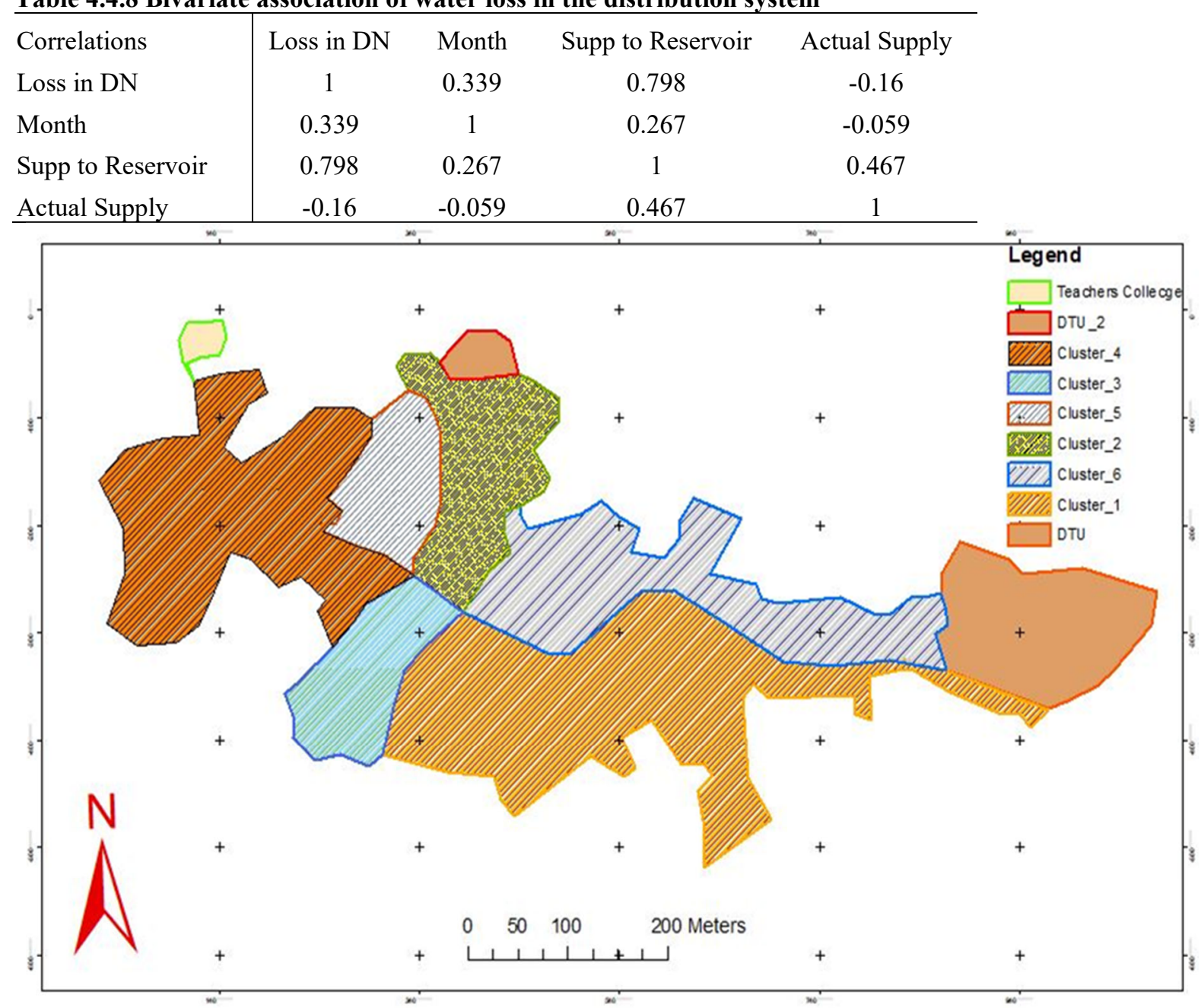

Figure 4.2.3 The area of Debre Tabor town distribution-network

Total Unaccounted for Water Losses

The Debre Tabor town drinking water supply scheme was produced $2290.41 \mathrm{~m}^{3} / \mathrm{d}$. However, in developing countries operation and maintenances are poor and not give adequate attention as new construction and system 
extensions (Hoko \& Alida, 2017) and the major problem of urban drinking water supply scheme is leakage (Mandefro \& Habtamu, 2017). Due to this, more than half of the supplied water for Debre Tabor town is lost in the system before reaching the consumers.

Average daily production of water before PH1 or water in TPL1, water in the collector pipelines before PH3 and an average flow of water in TPL2 were $1211.96,868.97$ and $524.43 \mathrm{~m}^{3} / \mathrm{d}$. However, the daily losses of water were $253.01,419.4$ and $90.72 \mathrm{~m}^{3} / \mathrm{d}$ through TPL1, in the collector pipelines before PH3 and TPL2 respectively. The total losses of water in the transmission and collector pipelines except TPL3, 4 and 5 were $763.13 \mathrm{~m}^{3} / \mathrm{d}$. An average $\mathrm{m}^{3} / \mathrm{d}$ water produced before TPL3, TPL4 and TPL5 were 433.71, 134.65 and 958.95 respectively. Therefore, the total supplied volume of water to the reservoirs passing through TPL3, 4 and 5 were $1527.313 \mathrm{~m}^{3} / \mathrm{d}$ without accounting losses in the TPL3, 4 and 5. Moreover, an average daily consumed water in the town in each cluster was $886.93 \mathrm{~m}^{3} / \mathrm{d}$. This shows that, the total losses of water in the DN including TPL3, 4 and 5 were $640.4 \mathrm{~m}^{3} / \mathrm{d}$. Therefore, the total losses of water in the system were $1403.53 \mathrm{~m}^{3} / \mathrm{d}$.

The total cubic meter UFW in the system was covered $61.28 \%$ from the total production of water, out of this $27.96 \%$ of water was lost in the DN and $33.32 \%$ of water was lost in the TPLs. Similarly, out of the total TPLs losses of water, TPL1, TPL2 and collector pipes before PH3 were covered $11.05 \%, 4 \%$ and $18.31 \%$ respectively. The specific losses of water in TPLs or losses in the DN for Debre Tabor town particularly higher than the total allowable water losses standards.

The total supplied water without accounting water losses in the system was covered $59.5 \%$ of the total town water demand. It could cover a continuous supply of water for 14 hours and 18 minutes per day. However, in developing countries including Ethiopia water loss is a major challenge of drinking water demand (Asmelash, 2014) for Debre Tabor town in particular. The total losses of water in the system were covered $61.28 \%$ from the total supplied water and it would cover $8 \mathrm{hr}$ and $45 \mathrm{~min}$ daily supply.

Nevertheless, according to FDRE ministry of water (Water Supply \& Sanitation, 2019) water loss principal, Debre Tabor town drinking water supply system should be lost 572.6 or $687.12 \mathrm{~m}^{3} / \mathrm{d}$ and it should be supply 1717.81 or $1603.3 \mathrm{~m}^{3} / \mathrm{d}$ at minimum and maximum percentage of acceptable water loss standards respectively. These losses of water were covered $44.6 \%$ or $41.63 \%$ of the total town water demand and it could be supplied $10.7 \mathrm{hr}$ or $9.99 \mathrm{hr}$ per day. As per (Amhara Water Resources Bureau, 2012) water loss standard, the town actual drinking water supply should be $1695 \mathrm{~m}^{3} / \mathrm{d}$, it would cover $44 \%$ of the total town water demand and it could be supplied $10.6 \mathrm{hr}$ every day with $595.51 \mathrm{~m}^{3} / \mathrm{d}$ water losses. Similarly, based on WHO water loss standards Debre Tabor town actual supply should be 1717.81 or $1259.73 \mathrm{~m}^{3} / \mathrm{d}$ with $44.6 \%$ or $32.71 \%$ of the town drinking water demand at 572.6 or $1030.7 \mathrm{~m}^{3} / \mathrm{d}$ water losses. It should be supplied for 10.7 or 7.85 hours per day respectively at minimum and maximum WHO water losses standard. The perfect drinking water provision is a qualified aid of managements (Balogun et al., 2017) and impossible to make continues to supply in high leakage rates (Ilaya-Ayza, 2017). The Debre Tabor town water supply system was lost $1403.6 \mathrm{~m}^{3} / \mathrm{d}$ and it supplied $886.8 \mathrm{~m}^{3} / \mathrm{d}$. This actual supply of water is only covered $23.03 \%$ of the total town water demand with 5.53 hour daily supply. Even though this actual supply of water is not distributed in the right way since the town residents were assimilated pipe water within once per 15 to 30 days.

Table 4.7.17 Total losses of water in the system in $\mathrm{m}^{3} / d$

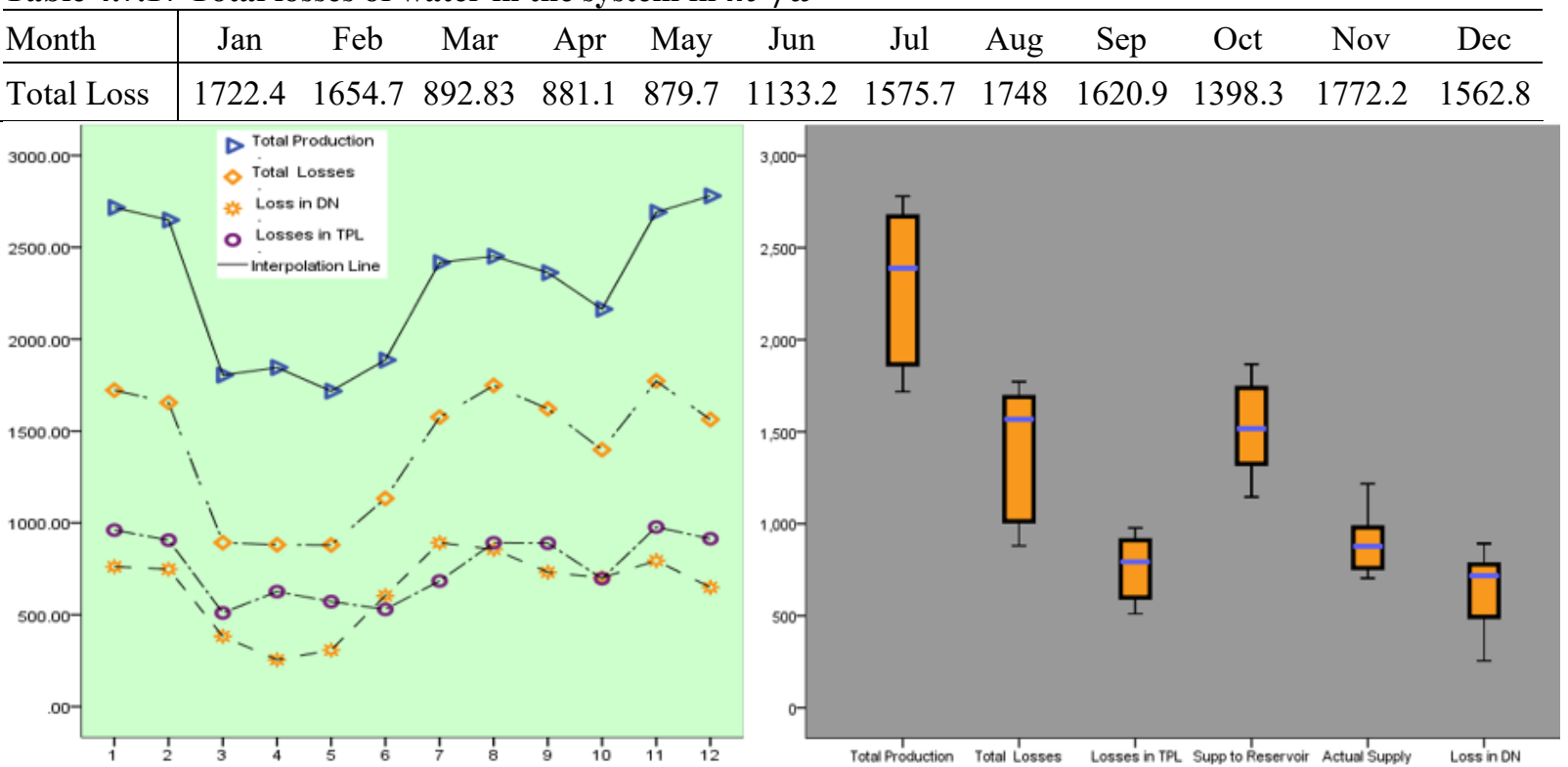

Figure 4.7.5 Total production and losses of water in the system from Jan to Dec (1 to 12) 
Table 4.7.18 Bivariate associations of the total losses of water in the system

\begin{tabular}{l|cccccc}
\hline Correlations & $\begin{array}{c}\text { Total } \\
\text { Losses }\end{array}$ & Month & Total Production & $\begin{array}{c}\text { Losses } \\
\text { in TPL }\end{array}$ & Actual Supply & $\begin{array}{c}\text { Loss } \\
\text { in DN }\end{array}$ \\
\hline Total Losses & 1 & 0.338 & 0.93 & 0.897 & 0.056 & 0.93 \\
Month & 0.338 & 1 & 0.286 & 0.275 & -0.059 & 0.339 \\
Total Production & 0.93 & 0.286 & 1 & 0.928 & 0.42 & 0.786 \\
Losses in TPL & 0.897 & 0.275 & 0.928 & 1 & 0.306 & 0.673 \\
Actual Supply & 0.056 & -0.059 & 0.42 & 0.306 & 1 & -0.16 \\
Loss in DN & 0.93 & 0.339 & 0.786 & 0.673 & -0.16 & 1 \\
\hline
\end{tabular}

Non-Revenue Water (NRW)

The apparent loss of water is included customer metering error, improperly sized meter or wrong types of water meter, data management mistakes and unauthorized consumptions. The customer's water meter gradually large and the cumulative volume of water are passed through them over time caused the meters to under-register flow of water. These occurrences are common with smaller residential meters of size 5/8inch and 3/4inch (NRW Auditing Software, 2014). For a meter size 1-inch and large typical of multi-unit residential, commercial and industrial accounts meter under-registration can occur from improper application of the meter i.e. install the wrong types of a meter or the wrong sizes of the meter from the flow pattern or profiles of the consumer (NRW Auditing Software, 2014). For instance, many large meters have reduced accuracy at low flows if an oversize meter is installed, most of the time the routine flow will occur in the low flow range of the meter and a significant portion of it may be registered (NRW Auditing Software, 2014). The meter accuracy testing and electronic calibration of related instrumentation are conducted annually less than $10 \%$ founded $6 \%$ accuracy (NRW Auditing Software, 2014).

The system data handling errors are apparent losses caused by accounting omissions. Systematic data handling errors resulting in a direct loss of revenue potential. The utility measures water consumptions are registered by water meters at consumer premises. The meter should be read monthly and the data transformed into the billing system which generates and send as a bill to the customer. The data transformation error results in the consumption value being less than the actual use creating an apparent loss. Such error might occur from illegible and miss recorded hand-written readings compiled by metering readers, imputing an incorrect meter registering, and unite conversion of meter reading equipment. The utility had not yet gathered detailed assessment of systematic data handling error which is recommended that apply $0.25 \%$ of billed consumption volume of water, but negative values are not allowed (NRW Auditing Software, 2014).

The authorized consumption volume of water is metered or unmetered water the consumers are used. It is the water utilities own uses and use of others who are implicitly or explicitly authorized to do so by the water utility. Which are typically in non-revenue water including water for firefighting, flushing, street cleaning, watering of gardens and public fountains. This volume of water cover $1.25 \%$ of the the total supplied volume of water (NRW Auditing Software, 2014). This may include both metered and unmetered consumption of water. The unbilled metered water is certified by water utility for any purpose which is understood by the utility procedure to be unbilled. This included metered water consumption by the utility itself in the treatment or distribution, metered water provided for civic institutions free of charge.

The unauthorized consumption of water includes illegally connection, bypasses to customer meters and /or tampering with meter reading equipment which is not collect revenue. In most water utility this volume of water did not yet gather detailed data it is recommended to apply $0.25 \%$ of the capacity of supplied water but zero value is not accepted, since all water utility has some volume of unauthorized consumption (NRW Auditing Software, 2014).

The NRW is the outlines of apparent and real loss interims of unbilled metered consumption and /or unbilled unmetered consumption. This is water does not provide revenue potential to the utility. 
Table 4.5.1 Total annual non-revenue water and the amount of birr that was lost

\begin{tabular}{l|l|cc}
\hline \multicolumn{2}{c}{ Type Group } & $\mathrm{m}^{3} /$ year & ETB \\
\hline \multirow{3}{*}{ Supplied water } & Source & 835999 & N/A \\
& Imported & N/A & N/A \\
& Exported & N/A & N/A \\
& Total supplied & 835999 & N/A \\
\hline \multirow{5}{*}{ Authorized consumption } & Billed metered & 323731 & N/A \\
& Billed unmetered & N/A & N/A \\
& Unbilled metered & 10450 & N/A \\
& Unbilled unmetered & 334181 & N/A \\
\hline \multirow{2}{*}{ Water losses } & Total authorized & 512278 & 9647902.3 \\
\hline \multirow{2}{*}{ Apparent losses } & UFW & 2090 & 39361.6 \\
\cline { 2 - 4 } & Unauthorized consumption & 20664 & 389165.6 \\
& Customer metering inaccuracy & 809 & 15242.3 \\
Real losses & Data handling error & 23563 & 443769.5 \\
\hline Non-revenue water & Total apparent losses & 488715 & 9204132.8 \\
\cline { 2 - 4 } & Current annual real losses & 522728 & 9844710.5 \\
\hline
\end{tabular}

\section{CONCLUSIONS}

The total production of water was covered $59.5 \%$ of the total town water demand and it is satisfied for $14 \mathrm{hr}$ and $18 \mathrm{~min}$ daily supply in 2020 . However, out of the total town water production 763.13 and 640.4 cubic meter water per day was lost in the transmission pipelines (TPL) and in the distribution network (DN). Therefore, the total losses of water in the entire water supply system $\left(1403.53 \mathrm{~m}^{3} / \mathrm{d}\right)$ were covered $27.96 \%$ in the distribution network and $33.32 \%$ in the transmission pipelines. Therefore, the actual supply of water $\left(886.88 \mathrm{~m}^{3} / \mathrm{d}\right)$ in the system at $61.28 \%$ total loss was supplied for 5 hours and 32 minutes per day. However, it would cover 7.85 to 10.7 hours per day from the allowable water loss standards. Therefore, the losses of water for the Debre Tabor town water supply system were not compulsory which was higher than the total actual supply of water. This confirms that, the Debre Tabor town water supply systems are deteriorated and it is a series cause of town drinking water shortage.

\section{REFERENCES}

Alubel. (2018). Heritage Potentials and Management Challenges in Debre Tabor Town, Ethiopia. 7(3), 1-20.

Amhara Water Resources Bureau. (2012). Amhara Water Resources Development Bureau Water Supply Core Process Water Supply Design Guideline, November 2012 (Issue November).

Asmelash. (2014). Assessing Water Supply Coverage and Water Losses from Distribution System for Planning Water Loss Reduction Strategies ( Case Study on Axum town, North Ethiopia ). 6(8), 82-88.

Balogun, I. I., Sojobi, A. O., \& Galkaye, E. (2017). Public water supply in Lagos State , Nigeria: Review of importance and challenges, status and concerns and pragmatic solutions. Cogent Engineering, 38, 1-21. https://doi.org/10.1080/23311916.2017.1329776

Chaminuka, L., \& Nyatsanza, T. D. (2013). An assessment of water shortages and coping mechanisms of Harare residents : A case of Msasa Park and Dzivaresekwa. 4(3), 21-35.

Debre Tabor Water Supply Design Report. (2019). Debre Tabor Water Supply Project Final Design Report (Issue April).

Hoko \& Alida. (2017). Investigating unaccounted for water and its components in Zomba City water supply system, Malawi Zvikomborero Hoko and Jessy Alida Chipwaila. 495-506. https://doi.org/10.2166/washdev.2017.003

Ilaya-Ayza. (2017). Multi-criteria optimization of supply schedules in intermittent water supply systems. Journal of Computational and Applied Mathematics 309 (2017) 695-703 Contents; Journal Homepage: Www.Elsevier.Com/Locate/Cam, 1-10.

Jang, D. (2018). A Parameter Classification System for Nonrevenue Water. 2018.

Mandefro \& Habtamu. (2017). Water supply and demand scenario of Dilla Town. 9(December), 270-276. https://doi.org/10.5897/IJWREE2017.0748

NRW Auditing Software, N. d. (2014). AWWA Water Audit Software Version 5.0. Developed by the Water Losses Control Committee of the American Water Work Association Aguste, 2014 (p. 2014).

Water Supply \& Sanitation. (2019). Federal Democratic Republic of Ethiopia Ministry of Water, Irrigation and Electricity Second Growth and Transformation National Plan for the Water Supply and Sanitation Sub-. 